\title{
BREEDING AND SEED PRODUCTION OF GREEN BACK MULLET, CHELON SUBVIRIDIS (VAL. 1836)
}

\author{
S. B. Saha* and M. F. Kabir \\ Bangladesh Fisheries Research Institute, Brackishwater Station, \\ Paikgacha, Khulna, Bangladesh
}

Green back mullet, Chelon subviridis (Val. 1836), earlier known as Liza subviridis is a brackishwater mugilid fish with a tropical Indo-pacific distribution. It is a euryhaline and eurythermal fish. This fish is locally known as Parse or Bata and commonly available in shallow coastal waters, estuaries and mangrove swamps of Bangladesh. The quality of flesh, high economic value and wide temperature and salinity tolerance capacity make this species popular for aquaculture in the intertidal ponds (Nlewadin and Deekae 1997). This fish is traditionally cultured with shrimp in the coastal impoundments (locally called ghers) of Bangladesh. At present, the farmers depend upon the wild seed for stocking to their ghers. Due to indiscriminate harvest from natural habitat and some environmental reasons, the abundance of this fish in nature is decreasing day by day. There is no alternate of supply of seed from artificial sources to conserve the natural biodiversity and increase production of this fish. This fish migrate to the sea during breeding period and again back towards coastal water where they pass their whole young life until the spawning period. Preliminary study on the breeding of Liza subviridis was conducted by Das (1992) in the south-west region of Bangladesh. After that, attempt was undertaken by no sector for developing breeding and seed production technology of this commercially important fish. Hsu et al. (2007) reported that mullets are winter breeder and the suitable breeding temperature is $20-23^{\circ} \mathrm{C}$. Age, growth, lengthweight relationship, sex ratio, stages of maturity and fecundity of the greenback mullet were studied by Al-Daham and Wahab (1991) and Rahman et al. (2013). Studies on the biology emphasizing length weight relationship, fecundity, reproductive characteristics and spawning of some other mullet species were conducted by Ergene (2000), Rheman et al. (2002) and Cherif et al. (2007). Realizing the importance of artificial production of fry of Chelon subviridis, attempt has been made to develop breeding and seed production technology of the species. The present communication describes the findings of the same.

*Author for correspondence. 
The study was conducted in February 2014. For breeding, matured male and females of Chelon subviridis were collected from on-station brackishwater ponds (water salinity, 4-10\%o) of Bangladesh Fisheries Research Institute, Brackishwater Station, Paikgacha, Khulna. The body weight of collected male fishes were ranged from 42-50 g and that of female fishes were from 50-58 g. After collection of broods, they were transported to the hatchery with pond water having $20^{\circ} \mathrm{C}$ temperature. Salinity of water was increased gradually to $30 \mathrm{ppt}$ by adding brine $(100 \%$ ) for a period of $48 \mathrm{hrs}$ and temperature of water was gradually increased up to $24^{\circ} \mathrm{C}$ using submersible heater fitted with thermostat to avoid stress. Both male and female fishes were administered with synthetic gonadotropin releasing hormone analogue (S-GnRH), commercially known as 'Ovupin' (Ningbo Sansheng Pharmaceutical Co. Ltd., Ningbo, China) at a single dose of $20 \mathrm{mg} / \mathrm{kg}$ body weight of fish. The hormone was injected in deep muscle at the base of the dorsal fin of the fish. The injected male and female fish were released at the ratio of 2:1 in 30\%o saline water in fibre glass tanks (Cap. 400 liters) provided with gentle aeration. The temperature of water of the tanks was maintained at a level of $24-25^{\circ} \mathrm{C}$. The fish spawned in the tank water.

After 32-36 hr. of administering hormone, the fishes showed spawning activity. At this stage, male and female fishes started pairing. The female release huge eggs with a jerk of its body and the male released spermatozoa and fertilized the eggs. The fertilized eggs were non-adhesive, spherical, transparent and shiny. The diameter of the fertilized eggs varied from $750-850 \mu$ with a single oil globule (Fig. 1) which made the eggs buoyant on the surface of water. The unfertilized eggs became opaque and whitish in colour.

After spawning, the fertilized eggs were transferred to separate tanks with water having same salinity and temperature for incubation. After 25 minutes of fertilization, a small periviteline space was formed in the fertilized eggs. This space gradually disappeared and cell division was started. The eggs attained gastrula stage (Fig. 2) after 6.00-7.00 hours and characteristics of narula stage (Fig. 3) appeared after 12.00-13.00 hours of fertilization. After 19-21 hours of fertilization, the fertilized eggs were hatched out in incubation tank. The newly hatched larvae (Fig. 4) with yolk sac and oil globule were black in colour and planktonic in nature showing jerking movement. The length of the newly hatched larvae was $2.00-2.50 \mathrm{~mm}$. After $3^{\text {rd }}$ day of hatching, the yolk sac was absorbed and mouth opening became visible. At this stage feed was supplied to the fry.

After hatching and yolk sac absorption, a portion of fries were fed with boiled and smashed egg yolk. For feeding larvae, Brachionus rotundiformes were cultured using Nannochloropsis and yeast as feed. Nannochloropsis was 
cultured in mass using Gillard's modified f/2 media (Gillard and Ryther, 1962) in the algal culture laboratory of Brackishwater Station. When the fries mouth opening became larger, nauplii of Artemia were supplied as feed.

The fries fed with egg yolk did not respond and died at $3^{\text {rd }}$ day of feeding. But the fries which were fed with rotifer grew well. Initially, rotifer was supplied at a density $5-6$ ind./ $\mathrm{ml}$ water and gradually increased by $2-3 i n d . / \mathrm{ml}$ daily with the growth of the fry. After 7 days, oil globule disappeared completely. The larvae appeared fish like appearance after $9^{\text {th }}$ day of hatching with pectoral fin (Fig. 5). After 12 days, when the mouth opening of the fries became larger, the Artemia nauplii were supplied as feed at a density of 6-7 ind./ $\mathrm{ml}$ water. After 20 days of rearing, other fins like dorsal, anal and caudal became very distinct and the fries attained the shape of adult fish (Fig. 6). As the fries grew to adult shape, they swam very actively in school.
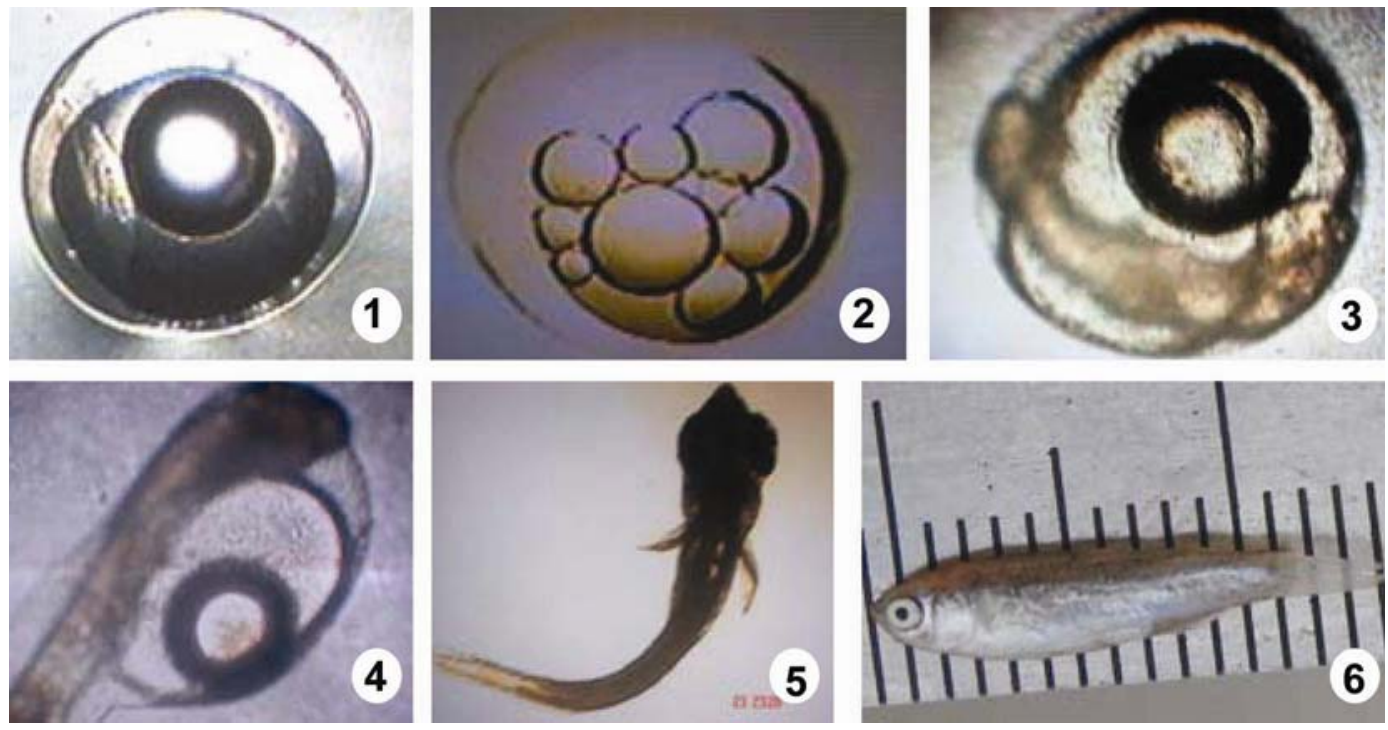

Figs.1-6: 1 Fertilized egg, 2: Gastrula stage, 3. Nerula stage, 4. Newly hatched larvae, 5. 12 days old fry, 6. 20 days old fry.

To maintain a congenial water quality level for the growth of larvae, 10-15\% water of the larval rearing tank was exchanged daily with fresh saline water with same salinity and temperature. Egg and fries were collected from the incubation tank periodically to observe the development under microscope.

Depending on the present encouraging findings, further research will be conducted on efficacy of different hormones with different doses, feeding and impact of water quality management on the breeding performance of Chelon 
subviridis in the next winter season for the development of complete technology of breeding and seed production of this fish. The findings of these researches will pave the way of conservation of natural stock and increasing production of this fish through aquaculture in the coastal ghers.

Acknowledgement: The technical support provided by WorldFish Center, Dhaka for developing micro-algae and rotifer culture system is highly acknowledged.

\section{LITERATURE CITED}

AL-DAHAM, N. K. and WAHAB, N. K. 1991. Age, growth and reproduction of the greenback mullet, Liza subviridis (Valenciennes), in an estuary in Southern Iraq. J. Fish Biol., 38(1):81-88.

CHERIF, M., ZARRAD, R., GHARBI, H., MISSAUI, H. and JARBOUI, O. 2007. Some biological parameters of red mullet Mullus barbatus L. from the gulf of Tunis. Acta Adriat.,48(2):131-144.

DAS, N. G. 1992. Artificial breeding of mullet (Liza subviridis). Final report presented to the Bangladesh Agricultural Research Council. Institute of Marine Sciences, University of Chittagong. 55p.

ERGENE, S. 2000. Reproductive characteristics of thinlip grey mullet, Liza ramanda (Risso) inhabiting Akgol-Paradeniz lagoons (Goksu delta). Turk. J. Zool., 245:159-164.

GILLARD, R. R. L. and RYHTHER, J. H. 1962. Studies of marine planktonic diatoms 1. Cyclotella nana (Hustedt) and Detonula confervaces (Cleve). Gran. Can. J. Microbiol., 8:229-239.

HSU, C.C., HAN, Y.S. and TZENG, W.N. 2007. Evidence of flathead mullet Mugil cephalus L. spawning in waters of northeast of Taiwan. Zoological Studies, 46(6):717-725.

NLEWADIM, A.A. and DEEKAE, S.N. 1997. Collection of juvenile mullet species from brackishwater tidal farm in Nigeria. NAGA, ICLARM Quarterly, 20:19-20.

RAHMAN, M. A. U., AJMAL KHAN, S., LYLA, P. S., KADHARSHA, K., MOHAN CHANDER, P. and AKBAR JOHN, B. 2013. Length-weight Relationship and Condition Factor of Liza subviridis (Valenciennes, 1836) of Parangipettai Waters, Southeast Coast of India. Pakistan J. Biol. Sci., 16(7): 345-350.

RHEMAN, S., ISLAM, M. L., SHAH, M. M. R., MONDAL, S. and ALAM, M. J. 2002. Observation on the fecundity and gonadosomatic index (GSI) of grey mullet Liza parsia (Ham.). Online J. Bio. Sci., 2(10):690-693. 